\title{
SIGURNOST, TERORISTIČKE UGROZE I NAMJERA PUTOVANJA TURISTA ${ }^{1}$
}

\section{SECURITY, TERORIST THREATS AND TOURIST TRAVEL INTENTION}

SAŽETAK: Posljednja dva desetljeća u javnosti se stvara percepcija terorizma kao globalnog problema. Mnoštvo informacija i vijesti koje su danas dostupne stvaraju dojam da je terorizam tu i sada te bude osjećaj straha. Prijašnja istraživanja su pokazala kako strah od terorizma utječe na donošenje odluke turista pri izboru destinacije. Stoga, glavni ciljevi ovog rada su istražiti: 1) koliku važnost ima sigurnost pri odabiru destinacije za putovanje za turiste te 2) kako izloženost turista medijskim objavama o terorističkim ugrozama utječe na namjeru posjete destinaciji koje su bile ranije pogođene terorističkim napadima. U ovom radu provedena su dva primarna istraživanja metodom online ankete na prigodnom uzorku od 118 domaćih i 94 stranih ispitanika koji koriste popularne turističke web portale. Nalazi istraživanja pokazuju da je sigurnost važan faktor u odabiru destinacije putovanja za turiste koji dolaze iz zemalja koje imaju visoku razinu izbjegavanja neizvjesnosti. Nadalje, nalazi pokazuju da povećana medijska izloženost vijestima koje se odnose na terorizam smanjuje namjeru turista da posjete odredište koje je bilo pogođeno terorizmom, ali samo u grupi turista s manje razvijenim kozmopolitskim identitetom.

KLJUČNE RIJEČI: terorizam, turizam, sigurnost destinacije, medijske objave, namjera putovanja turista, kozmopolitizam

ABSTRACT: For the last two decades, the public perception of terrorism has emerged as a global problem. The abundance of information and news that are available today gives

Dr. sc. Dario Miočević, Izvanredni profesor Sveučilište u Splitu, Ekonomski fakultet, Cvite Fiskovića 5, 21000, Split, Republika Hrvatska +385 914430 779, dmiocevi@efst.hr

** Marina Juric, mag.oecc Associate Product Management, VIP Sportstravel, Geneststrasse 5, 10829 Berlin, Njemačka, +385976222828, marina.juric@ymail.com

Ovaj rad je nastao kao rezultat diplomskog rada „Utjecaj sigurnosne krize u Europi na preferencije turista“ kojeg je izradila i pred povjerenstvom obranila Marina Jurić na Ekonomskom fakultetu, Sveučilište u Splitu. 
the impression that terrorism is here and now which creates a sense of fear. Previous research has shown how fear from terrorism influences tourist's decision making when he/ she chooses a destination. Therefore, the main goals of this paper are to investigate: 1) the importance of safety and 2) how tourists' exposure to media coverage of terrorist attacks influences the intention to visit a destination that was affected by terrorist attacks. In this paper, two studies were conducted using the online survey method on a convenient sample of 118 domestic and 94 foreign respondents who use popular tourist web portals. The findings show that safety is an important factor in choosing a destination for tourists that come from countries which have high levels of uncertainty avoidance. Furthermore, the findings show that increased media exposure to terrorism-related news decreases the tourist's intention to visit a destination but only among the group of tourists with less developed cosmopolitan identity.

KEY WORDS: terrorism, tourism, destination safety, media coverage, tourist travel intention, cosmopolitanism

\section{UVOD}

Turizam je složena gospodarska aktivnost koja na različite načine doprinosi životu ljudi kroz stvaranje novih poslova, utjecaja na kulturu i zabavu te svakodnevni život (Baker, 2014). Unatoč tome njegov razvoj ovisi o brojnim vanjskim čimbenicima uzrokovanih ljudskom aktivnošću poput terorizma, sigurnosti, kriminala, epidemija, političkih promjena, ekonomskih kriza i sl. Prethodna iskustva ukazuju kako su turisti često žrtve, ali i mete terorističkih napada (pr. bombaški napad u noćnom klubu na Baliju gdje su stradali mnogobrojni turisti). Zbog ove činjenice, sigurnost je postala jedan od ključnih čimbenika pri odlučivanju o odabiru turističke destinacije. Kao posljedica ovog procesa, događa se to da se nesigurne destinacije mijenjaju alternativnim destinacijama koje turisti percipiraju sigurnijima. Teroristički napadi mogu značajno naštetiti imidžu destinacije inicirajući pojavu straha kod potencijalnih turista. Posljedično, ni ekonomski uspjeh ne može zaštititi turističku industriju od negativnih utjecaja terorističkih napada (Albu, 2015). Sa svakodnevnim promjenama u poimanju sigurnosti destinacija, sektor turizma se sve više okreće razumijevanju kako potencijalne ugroze utječu na preferencije turista.

Polazeći od prijašnjih istraživanja, glavni cilj ovog rada je raščlanjivanje procesa odlučivanja turista o odabiru destinacije u uvjetima terorističkih ugroza (Fuchs, Uriely i Reichel, 2013; Kim, Schroeder i Pennington-Gray, 2017; Larsen et al., 2011; Sönmez i Graffe, 1998). Kako bi se postigao cilj, provedena su dva primarna istraživanja metodom online ankete. U prvom koraku, provedeno je elektroničko anketno ispitivanje na popularnom međunarodnom web portalu za organizaciju turističkih putovanja na uzorku od 94 ispitanika iz više zemalja gdje je glavni cilj bio utvrditi kako kulturološka dimenzija izbjegavanja neizvjesnosti (Hofstede, Hofstede i Minkov, 2010) utječe na sigurnost kao važan kriterij pri odabiru destinacija za putovanje. U drugom koraku, provedeno je online anketno ispitivanje na popularnom hrvatskom turističkom portalu za organizaciju na uzorku 118 ispitanika. Cilj ovog istraživanja je bio utvrditi kako emotivne reakcije na objave o terorističkim napadima u medijima utječu na spremnost ispitanika da se odluče za alternativnu destinaciju (onu koja nije pogođena terorističkim napadom), a pod moderatorskim utjecajem kozmopolitskog identiteta. 
Polazeći od ciljeva istraživanja, nalazi ovog istraživanje doprinose postojećoj literaturi koja izučava interakciju turizma i terorizma. Prvo, rezultati ukazuju kako je kulturološki profil važna determinanta koja utječe na to smatraju li putnici/turisti sigurnost važnom determinantom pri odabiru destinacije. Rezultati ukazuju da u kulturama koje imaju visoku razinu stupnja izbjegavanja neizvjesnih situacija, putnici pridodaju mnogo veću važnost sigurnosnim aspektima pri odabiru destinacije za putovanje. Drugo, ovaj rad ukazuje kako je izloženost medijskim objavama o terorističkim ugrozama važna determinanta hoće li turist i dalje imati želju posjetiti destinaciju koja je bila pogođena terorističkim napadom. Polazeći od argumenata Sönmez i Graffea (1998) koji smatraju da je pitanje zašto turisti izbjegavaju određene destinacije jednako relevantno kao i ono zašto odabiru druge destinacije, utvrđeno je da otpornost na objave u medijima pozitivno utječe na spremnost posjete destinaciji kod turista koji imaju razvijen kozmopolitski identitet.

\section{PREGLED LITERATURE}

\subsection{Terorizam}

Pojam terorizam potječe iz latinske riječi „terror“ koja označava „fizičko nasilje i strah namjerno izazvane javnim aktima nasilja, namjerna upotreba sredstava koja utječu na kolektivnu sigurnost" (Servier, 2002). Enciklopedija Britannica definira terorizam kao sustavnu upotrebu nasilja s ciljem stvaranja klime straha kod šire populacije, a kako bi se ostvario određeni politički ili ideološki cilj. Definicija terorizma vrlo je kompleksna, te je u popularnoj upotrebi razvila određenu stigmu. U početku, terorizam se poistovjećivao $\mathrm{s}$ nasilnim činom države prema domaćem neprijatelju, a od 19.-og stoljeća izraz se najviše koristi za nasilje usmjereno na političku vlast (izravno ili neizravno), a radi utjecaja na politiku ili iskaz otpora postojećem režimu (Albu, 2016). Tarlow (2006) ističe kako ne postoji generalni konsenzus tko je terorist ili koja je točna definicija terorizma. U literaturi se danas može naići na različite definicije terorizma što govori o širokom obuhvatu i poimanju pojma terorizma, ali i o kompleksnosti njegovog konceptualnog poimanja. Tako Schmid (2011: 2) navodi da se terorizam može promatrati kao zločin, politički čin, ratni sukob, komunikacijska strategija ili kao vjerski pokret. Za razliku od njih, Wilkinson (2002) ističe kako terorizam nije ni filozofija, ni pokret već isključivo sredstvo kojim se želi zastrašiti stanovništvo kako bi se izazvao strah i nesigurnost. Sönmez i Graefe (1998) se također slažu s ovim stajalištem te tvrde kako ne postoji jedinstveno usvojena definicija terorizma. Često citirani klišej 'onaj tko je nekome terorist, nekome je borac za slobodu' najbolje oslikava različite stavove koje stvaraju problem pri definiranju ovog koncepta. Schmid (2005) konstatira kako rimsko pravo prepoznaje dvije razine zločina; Mala Prohibita, pogrešno jer je zabranjeno i Mala Per Se, što predstavlja intrinzično zlo. Prethodno implicira prekršaj koji je nezakonit i u suprotnosti s pravnim okvirom, dok potonji predstavlja unaprijed osmišljeni čin zla, koji je loš sam po sebi, neovisno o zakonskim propisima i regulatornom okviru. Sve civilizirane nacije smatraju terorizam intrinzičnim zlom, što se posebno odnosi na napade koji predstavljaju sredstvo kojima se cilja na isključivo neborbene ciljeve gdje civili predstavljaju glavni cilj takvih napada. 


\subsection{Turizam i terorizam}

Istraživanje rizika u turizmu seže od 70-ih godina u djelima Cohena i Ploga koji su u svojim radovima odredili različite tipove turista kao i njihov odnos prema riziku. Tijekom 90-ih dolazi do značajnog broja istraživanja rizika u turizmu (Sönmez i Graefe, 1998; Pizam, 1997; Tsaur, Tzeng i Wang, 1997), a vrhunac je dosegnut nakon napada 11. rujna. Od tada terorizam postaje trend u turističkim istraživanjima. Prema recentnom teorijskom pregledu, područje interakcije turizma i terorizma je fragmentirano gdje dominiraju istraživanja ekonomskih, poslovnih i političkih efekata terorizma na turističku djelatnost (Dabić, Mikulić i Novak, 2017).

Terorizam danas vrlo lako prelazi državne granice, cilja na građane različitih zemalja i iskorištava tehnologiju, međunarodna putovanja i napredne informacijsko-komunikacijske kanale (Schlagheck 1998). Prema Richter i Waugh (1983), turizam može postati izvor političkog problema. Turizam također simbolizira kapitalizam, te turizam sponzoriran od vlade, predstavlja vladu za mnoge, stoga je napad na turistički ekosustav jedne države izjednačen s napadom na vladu te države. Takva vizija turizma u očima terorista nedvojbeno dovodi do negativnih osjećaja i žrtvovanja turista s ciljem postignuća vlastitih ciljeva. Isto tako, s obzirom da turizam donosi profit, teroristički napad na turističku industriju je istovremeno napad na gospodarstvo države i stjecanje prednosti pred vladajućima. Teroristički napadi su stoga usko povezani sa smanjenim brojem dolazaka turista, posebno inozemnih. S druge strane, turisti kojima je sigurnost ključan čimbenik odabira destinacije, nesigurne destinacije mijenjaju onim sigurnijima.

Unatoč niskom faktoru rizika, prijetnja terorizmom je stvarna jer turisti predstavljaju lake mete teroristima dok su turističke destinacije savršene mete terorističkih napada. Korstanje (2012) smatra kako su turizam i terorizam naizgled odraz dva potpuno različita svijeta. Turizam je nastao na osnovama slobodnog kretanja i putovanja putem kojeg se razvija kulturološka svijest te prihvaćanje tuđih ideja i običaja. S druge strane, motivi terorističkih napada su često vezani za religijske, nacionalističke ili etničke razloge, te je mnogima od njih cilj odbaciti vlast i nametanje stranih pravila i kultura, dok neki čak eksplicitno odbacuju zapadnjački način života na kojem je današnji turizam uglavnom baziran. Međutim, razvidne su i dvije bitne sličnosti turizma i terorizma. Prvo, proces globalizacije i tehnološkog razvoja koji je doveo do rasta turističke industrije ujedno je olakšao djelovanje teroristima kojima ovaj razvoj omogućava puno lakšu regrutaciju novih članova, razmjenu informacija, financiranje te samu organizaciju napada. Metode kojima se koriste današnji teroristi nisu naučene uz pomoć drevnih vjerskih tekstova, već kroz moderne metode vojne obuke te uz pomoć Interneta i modernih tehnologija.

Drugo, turizam i terorizam se gotovo u jednakoj mjeri oslanjaju na medije. U turizmu je potrebno uvjeriti potencijalne posjetitelje da određena destinacija pruža sve tražene atribute koji zadovoljavaju njihove potrebe. S druge strane, teroristi putem medija pokušavaju demoralizirati svoje brojčano moćnije suparnike i uvjeriti ih da ne mogu pobijediti. Organizacije poput Al-Qaeda ili Islamske države traže veliku pozornost emitirajući masovna smaknuća žrtava, dijelom da bi zastrašili zapad, a dijelom kako bi zainteresirali nove članove i financijere da im se pridruže.

Aktualne studije su ukazale kako ne postoji linearna veza između terorizma i broja turističkih dolazaka (Asongo et al., 2019), a naročito u dugom roku (Liu i Pratt, 2017) uka- 
zujući na to da na mikroekonomskoj razini turisti različito percipiraju rizik od terorizma što utječe na njihove odluke vezano uz putovanja poput odabira i planiranja putovanja. Na slici 1 prikazan je konceptualni model istraživanja nakon kojega slijede hipoteze istraživanja.

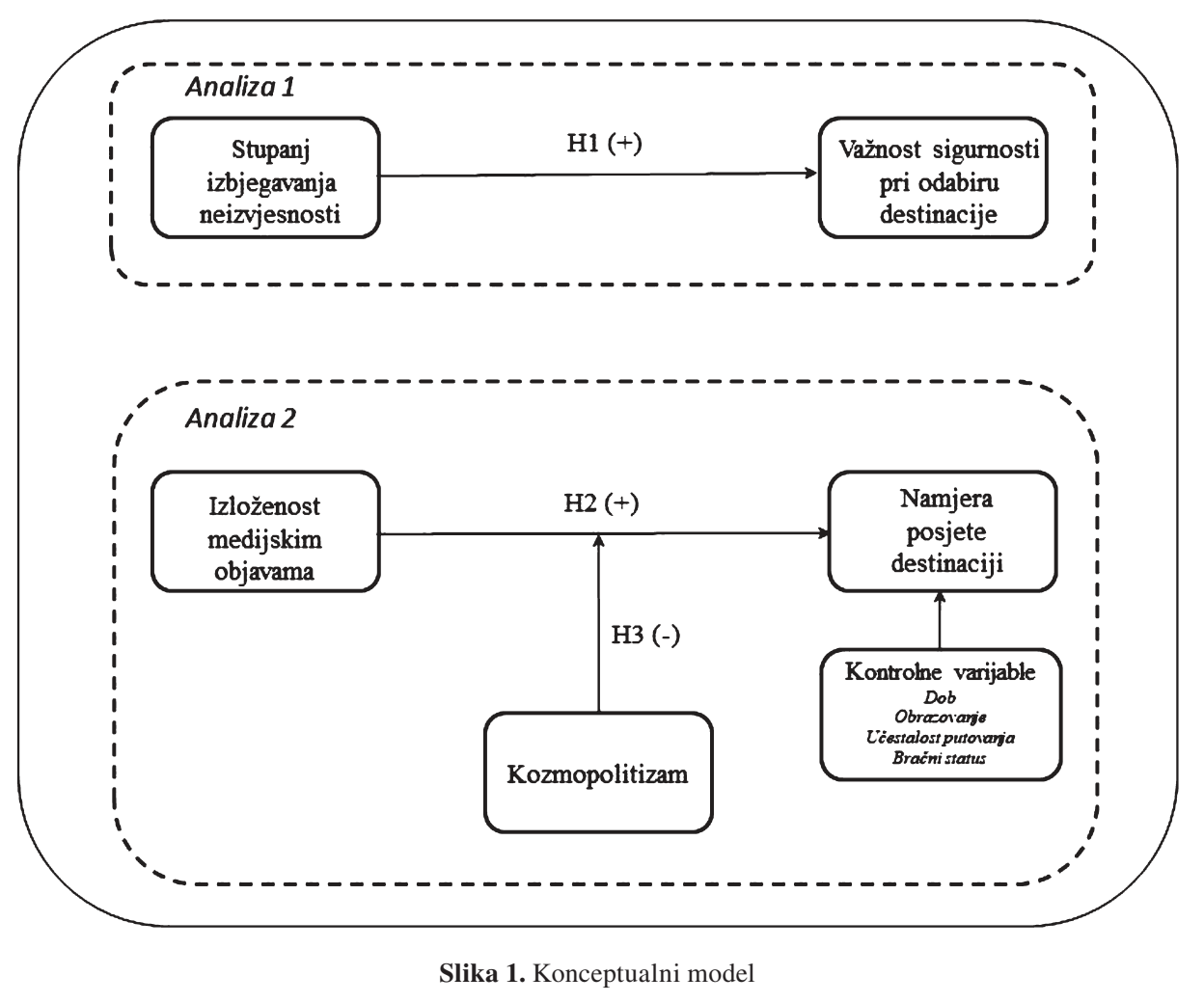

\section{HIPOTEZE}

\subsection{Izbjegavanje neizvjesnosti i sigurnost}

Sigurnost u najužem smislu definiramo kao izostanak opasnosti ili ugroze pojedinca. Prema Baldwinu (1997), sigurnost se određuje u odnosu na: 1) aktere čije vrijednosti treba osigurati, 2) na sami sustav vrijednosti, 3) potrebnu razinu sigurnosti, 4) prepoznate prijetnje, 5) način nošenja s prijetnjama te 6) relevantni period na koji se ugroza odnosi. Wolfendale (2007) navodi kako je sigurnost relativna pojava te da ne postoji u apsolutnom obliku te da pojedinci mogu osjećati manje ili više sigurnosti u odnosu na vanjske ugroze. Doživljaj sigurnosti predstavlja jedan od ključnih ljudskih doživljavanja stvarnosti, njegovog fizičkog i psihičkog razvoja, te napretka u sredini u kojoj živi, radi i stvara. Čovjek u svakodnevnom životu stremi sigurnosti, koju demokratsko društvo pokušava zaštititi i jamčiti putem raznih pravnih mehanizama i institucija (Horjan i Šuperina, 2012). Problem sigurnosti nikad nije bio važniji nego danas, ne samo za zajednicu već i za turizam s obzi- 
rom da je sigurnost osnovna potreba u svim sferama ljudske aktivnosti, uključujući turizam (Baker, 2014). Čavlek (2002) smatra da mir i sigurnost predstavljaju osnovne preduvjete za normalan razvoj destinacije, regije i države te predstavljaju osnovne čimbenike rasta. Bez navedenih uvjeta, destinacija postaje manje konkurentna na tržištu, čak i ako koristi najbolje marketinške kampanje te ističe najatraktivnije prirodne i ostale resurse. Danas se posebna pozornost pridaje zaštiti ljudskih prava i sloboda te životu u uvjetima potpune sigurnosti. Stoga isticanjem kako je destinacija sigurna, dionici u turističkom ekosustavu žele privući što veći broj posjetitelja (Reisigner i Mavondo, 2005).

Korstanje (2017) preispituje koncept sigurnosti naglašavajući kako svaka kultura, država ili bilo koja druga vrsta ljudske i društvene organizacije razvija vlastiti koncept što je sigurno, a što opasno. Prema opsežnom istraživanju koje su proveli Hofstede, Hosftede i Minkov (2010), zemlje se razlikuju i po tome koliko su spremne prihvatiti neizvjesne situacije (eng. Uncertainty avodiance indeks - UAI). Nedostatak osjećaja sigurnosti predstavlja jednu od neizvjesnih situacija. Prema provedenim istraživanjima uočeno je da se percepcija sigurnosnog rizika razlikuje u različitim kulturama (Bi i Gu, 2019; Kim, Schroeder i Pennington-Gray, 2017). Korstanje se osvrće na Inbakarana i Poyyamolia (2010) koji tvrde da se turizam zasniva na dva poriva. $S$ jedne strane pojedinac je motiviran da istraži nove krajeve i kulture (turistička potreba) dok s druge strane postoji urođena potreba koja se odnosi na osjećaj sigurnosti koji omogućava pojedincu da se osjeća ugodno. Stoga, može se postaviti hipoteza da će u kulturama s višim stupnjem izbjegavanja neizvjesnosti, putnici dodijeliti veću važnost aspektu sigurnosti kao kriteriju za odabir destinacije.

H1: U kulturama s višim stupnjem izbjegavanja neizvjesnosti, veći je i naglasak na sigurnosnom aspektu pri odabiru destinacije za putovanje

\subsection{Izloženost medijskim objavama i namjera putovanja turista}

Sönmez (1998) tvrdi da prijetnja koja je povezana s mogućnošću terorističkog napada zastrašuje turiste više nego bilo koja druga ljudska ili prirodna katastrofa. Terorizam utječe na turizam puno više nego na druge industrije i gospodarske grane. Razlog ovome je činjenica da je cilj terorizma širenje straha, čime se izravno i značajno ugrožava osnovna ljudska potreba za sigurnošću. Prema Maslowljevoj piramidi potreba pojedinac tek kada zadovolji osnovne ljudske potrebe koje uključuju sigurnost, on stremi ostvarivanju viših potreba, poput samoostvarivanja (npr. putovanjem). Unatoč tome u stvarnosti je turbulentna sigurnosna situacija već pokazala svoj utjecaj na turistički razvoj u mnogim zemljama i regijama. Turizam kao uslužni gospodarski sektor izložen je utjecaju različitih kriza. Posebnu ranjivost pokazuje zbog smanjene potražnje nakon terorističkih napada, što rezultira značajnim ekonomskim gubicima.

Turisti mijenjaju nesigurne destinacije kako bi izbjegli rizik od terorističkog napada. Istraživanja su pokazala da su učinci terorističkog napada kratkotrajni, te da se nakon početnog šoka turisti počnu vrlo brzo vraćati u destinaciju. Pizam i Fleischer (2002) tvrde kako se destinacije puno lakše oporave nakon jednog snažnijeg napada, nego nakon više učestalih napada koji dugoročno iniciraju više negativnih posljedica. Među najznačajnijim posljedicama su izraženo smanjenje turističke potražnje te izostanak prihoda od turizma dok se javlja i cijeli niz ostalih negativnih posljedica, kao što su pad zaposlenosti u turizmu, 
gubitak u poslovanju te slabije korištenje smještajnih i drugih kapaciteta (McKercher i Hui, 2003). Terorističkih napada je uvijek bilo, i uvijek će ih biti jer teroristi moraju naći način kako bi zadržali interes javnosti za njihove aktivnosti. S obzirom da ne postoji nešto što se zove apsolutna sigurnost, teroristički napadi se mogu dogoditi bilo kad i bilo gdje, te ih je vrlo teško predvidjeti, a na turističkoj industriji je da se nosi s tom ugrozom putem alata kriznog menadžmenta. Vijesti o terorističkim napadima čine prijetnje stvarnima, iako je mala vjerojatnost da će život pojedinca biti ugrožen. Pretpostavlja se da osobe koje dobivaju više informacija i novosti o terorističkim ugrozama osjećaju i veći strah od napada u odnosu na one koji su izloženi manjem broju informacija (Hoffman, 2013). Literatura koja izučava interakciju turizma i terorizma često naglašava kako je medijsko izvještavanje o terorizmu od presudne važnosti za percipirani rizik turista prilikom odabira destinacija za putovanja, naročito kod turista koji nisu imali ranije iskustva sa situacijama sigurnosnih ugroza (Larsen et al., 2011). Stoga se može postaviti sljedeća hipoteza:

H2: Povećana izloženost medijskim objavama o terorističkim ugrozama utječe negativno na namjeru putovanja u destinaciju koja je bila pogođena terorističkim napadom

\subsection{Moderirajući utjecaj kozmopolitizma}

Postojeća literatura generalno podržava tezu kako turisti izbjegavaju destinacije koje percipiraju kao rizičnije. Ipak određene studije pokazuju da neki turisti namjerno sudjeluju u rizičnim aktivnostima i posjećuju rizične destinacije (Korstanje, 2017; Bianchi, 2007; Smith, 2010). Potrebno je naglasiti kako je rizik subjektivan koncept koji se mijenja ovisno o vremenu i prostoru. Rezultati prijašnjih studija sugeriraju da utjecaj prijetnje od terorizma putem medijskih objava na odabir destinacije za putovanje ovisi o cijelom nizu faktora među kojima se aspekti ponude, način putovanja i karakteristike pojedinca čine najznačajnijima (Walters, Wallin i Hartley, 2019). Istraživanja su također pokazala kako turisti ponekad krive medije za pretjerano potenciranje vijesti o terorizmu što u konačnici čimbenik sigurnosti stavlja u drugi plan pri njihovom odlučivanju o odabiru destinacije (Fuchs, Uriely i Reichel, 2013).

Literatura koja se bavi turizmom je identificirala posebnu vrstu turista, tzv. alocentričari koji vole nestrukturirana putovanja u neobična mjesta i više dodira s lokalnim kulturama. Oni su samopouzdaniji, manje anksiozni, motivirani novostima, otkrićem i traže aktivni odmor koji će im omogućiti istraživanje fizičkih i kulturnih svjetova oko njih (Plog, 2002). U nizu eksperimentalnih studija, Kapuściński i Richards (2016) su uočili kako turisti koji svojim putovanjima pristupaju neplanski, tj. kojima je glavni cilj putovanja stjecanje novih i nepredviđenih iskustava te upoznavanja novih kultura i običaja, slabije reagiraju na medijske objave o signurnosnim ugrozama. U kontekstu društvenih znanosti, posebna pozornost se pridodaje konceptu kozmopolitizma kao tendenciji pojedinca da se otvori prema nepoznatome i da istražuje nove situacije, običaje i kulture (Hannerz, 1990). U teorijskoj diskusiji Swain (2009) ističe kako kozmopolitski identitet nije razvijen jednako kod svih ljudi koji putuju te neki od njih nemaju kozmopolitske motive prilikom planiranja putovanja. Uzimajući sve prethodno, može se zaključiti kako će kod turista koji imaju razvijeniji kozmopolitski identitet, utjecaj medijskih objava o sigurnosnim ugrozama manje utjecati na namjeru putovanja u destinaciju koja je bila pogođena nekim oblikom terorizma. Turisti 
koji imaju razvijen kozmopolitski identitet su motivirani posjetiti destinaciju zbog stjecanja novih iskustava u interakciji s kulturom zemlje domaćina te su na taj način manje podložni utjecajima medijskih objava o terorističkim ugrozama.

H3: Kozmopolitizam negativno moderira vezu između povećane izloženosti medijskim objavama i namjere putovanja u destinaciju koja je bila pogođena terorističkim napadom

\section{METODOLOGIJA}

Za potrebe ovog rada provedena su dva istraživanja korištenjem metode anketnog ispitivanja. Prvo istraživanje je provedeno na prigodnom uzorku. Cilj prvog istraživanja je bio utvrditi na koji način kulturološki referentni okvir (mjeren putem stupnja izbjegavanja neizvjesnosti) utječe na važnost sigurnosti kao kriterija pri odabiru destinacije za putovanje. Istraživanje je provedeno putem popularnog međunarodnog portala za putovanja te je istraživanju pristupilo 94 ispitanika. Anketna pitanja postavljena su na engleskom jeziku. Drugo istraživanje je provedeno također na prigodnom uzorku. Cilj drugog istraživanja je bio utvrditi na koji način izloženost medijskim objavama o terorističkim ugrozama i kozmopolitski identitet turista utječu na namjeru turista da posjete destinaciju koja je bila pogođena terorističkim napadom. Istraživanje je provedeno na popularnom hrvatskom portalu za putovanja te je istraživanju pristupilo 118 ispitanika te su anketna pitanja postavljena na hrvatskom jeziku. Uz dozvolu i suglasnost administratora oba portala (međunarodnog i domaćeg), poveznica na anketni upitnik je postavljena putem stranice portala na popularnoj društvenoj mreži Facebook. Korisnici koji posjećuju stranicu odabranih portala su zamoljeni da pristupe anketnom ispitivanju. Oba anketna ispitivanja su provedena u periodu od svibnja do srpnja 2018. godine.

\subsection{Operacionalizacija varijabli}

Varijable u ovom istraživanju su mjerene putem već etabliranih ljestvica iz prijašnjih istraživanja (Dolincar, 2007; Sönmez i Graefe, 1998). Podatci za stupanj izbjegavanja neizvjesnosti po zemljama su preuzeti iz Hofstede, Hofstede i Minkov (2010). Važnost sigurnosti kao kriterija pri odabiru destinacije je mjerena iskazivanjem stava ispitanika na tvrdnju „U kojoj mjeri vam je važna sigurnost pri odabiru destinacije“ na Likertovoj skali od 1 do 5 (1-vrlo mi je važna, 5-nije mi uopće važna). Zavisna varijabla „Namjera posjete destinaciji“ je mjerena iskazivanjem stava ispitanika na tvrdnju: „Biste li u budućnosti posjetili zemlju koja je bila subjekt terorističkog napada?" na binarnoj skali $(0-\mathrm{Ne}, 1-\mathrm{Da})$. Izloženost medijskim objavama o terorističkim napadima je mjerena iskazivanjem stava ispitanika na tvrdnju: „U kojoj mjeri čitate vijesti o terorističkim napadima? “ na Likertovoj skali od 1 do 5 (1- Učestalo čitam vijesti o terorističkim napadima, 5 - Nikad ne čitam vijesti o terorističkim napadima). Kozmopolitizam je mjeren mjernom skalom preuzetom iz istraživanja Cleveland et al. (2014) gdje su se koristile sljedeće čestice: 1. Volim promatrati ljudi iz drugih kultura da vidim što mogu naučiti od njih; 2. Zainteresiran sam učiti više o ljudima koji žive u drugim zemljama; 3. Uživam u razmjeni ideja s ljudima iz drugih kultura i zemalja; 4. Volim učiti o drugim načinima života; 5. Uživam biti u društvu ljudi 
iz drugih kultura kako bih učio o njihovim jedinstvenim pogledima i pristupima. Navedene čestice su mjerene na Likertovoj skali od 1 do 7 (1 - U potpunosti se ne slažem, 7 - U potpunosti se slažem).

Osim temeljnih varijabli u modelu, u drugom istraživanju su uključene kontrolne varijable za koje također smatra da mogu imati utjecaj na namjeru turista za posjet destinaciji koja je bila pogođena terorističkim napadom: dob, razina obrazovanosti te bračni status ispitanika (Park i Reisinger, 2010). Isto tako, prethodna iskustva tijekom putovanja utječu na percepciju rizika kod turista na način da turisti koji češće putuju spremniji su na prihvaćanje rizika, te njihovo prethodno iskustvo utječe na odabir buduće destinacije (Yang, Sharif i Khoo-Lattimore, 2015).

\section{REZULTATI}

\subsection{Rezultati analize stavova inozemnih turista}

Anketnom ispitivanju za potrebe prvog istraživanja pristupilo je 94 ispitanika. Demografske karakteristike i zemlja podrijetla ispitanika prikazane su u Tablicama 1 i 2.

Tablica 1. Demografske karakteristike ispitanika u analizi 1

\begin{tabular}{|c|c|c|}
\hline & Broj & Udio \\
\hline \multicolumn{3}{|l|}{ Spol } \\
\hline $\mathrm{M}$ & 41 & 43,6 \\
\hline$\check{Z}$ & 53 & 56,4 \\
\hline \multicolumn{3}{|l|}{ Dob } \\
\hline $18-25$ & 47 & 50,0 \\
\hline $25-30$ & 28 & 29,8 \\
\hline $30-35$ & 5 & 5,3 \\
\hline $35-40$ & 3 & 3,2 \\
\hline $40-50$ & 11 & 11,7 \\
\hline \multicolumn{3}{|l|}{ Obrazovanje } \\
\hline Magistar & 39 & 41,5 \\
\hline Prvostupnik & 34 & 36,2 \\
\hline Srednja škola & 21 & 22,3 \\
\hline \multicolumn{3}{|l|}{ Bračni status } \\
\hline Neoženjen/Neudana & 77 & 81,9 \\
\hline Oženjen/Udana & 16 & 17,0 \\
\hline Razveden/Razvedena & 1 & 1,1 \\
\hline $\mathbf{N}$ & 94 & 100,0 \\
\hline
\end{tabular}


Tablica 2. Zemlja podrijetla ispitanika u analizi 1

\begin{tabular}{|l|c|c|}
\hline \multicolumn{1}{|c|}{ Zemlja } & Broj & Udio \\
\hline Albanija & 3 & 3,2 \\
\hline Belgija & 14 & 14,9 \\
\hline Bugarska & 1 & 1,1 \\
\hline Francuska & 5 & 5,3 \\
\hline Njemačka & 14 & 14,9 \\
\hline Republika Irska & 2 & 2,1 \\
\hline Italija & 18 & 19,2 \\
\hline Litva & 2 & 2,1 \\
\hline Luksemburg & 1 & 1,1 \\
\hline Sjeverna Makedonija & 1 & 1,1 \\
\hline Crna Gora & 1 & 1,1 \\
\hline Nizozemska & 1 & 1,1 \\
\hline Norveška & 1 & 1,1 \\
\hline Poljska & 1 & 1,1 \\
\hline Portugal & 4 & 4,3 \\
\hline Rumunjska & 2 & 2,1 \\
\hline Rusija & 1 & 1,1 \\
\hline Srbija & 1 & 1,1 \\
\hline Slovenija & 3 & 3,2 \\
\hline Španjolska & 8 & 8,5 \\
\hline Švedksa & 3 & 3,2 \\
\hline Turska & & $\mathbf{1 0 0 , 0}$ \\
\hline UK & 3 & \\
\hline N & & \\
\hline
\end{tabular}

Kako bi se testirala hipoteza H1, koristio se test analize varijance (ANOVA). Prije same analize, napravljena je medijanska podjela uzorka prema stupnju izbjegavanja neizvjesnosti zemalja iz koje ispitanici dolaze. Prema rezultatima istraživanja uočljivo je da postoji statistički značajna razlika između stupnja neizvjesnosti i važnosti sigurnosnog aspekta pri odabiru destinacije za putovanje $(F(1,92)=3.942, p<0.05)$. Nalazi istraživanja ukazuju kako se u kulturama koje karakterizira visok stupanj izbjegavanja neizvjesnosti stavlja veći naglasak na sigurnost kao kriterij pri odabiru destinacije za putovanje. Na temelju nalaza istraživanja moguće je prihvatiti hipotezu H1 kao istinitu.

\subsection{Rezultati analize stavova domaćih turista}

Anketnom ispitivanju za potrebe drugog istraživanja pristupilo je 118 ispitanika. Demografske karakteristike ispitanika iz uzorka su prikazane u Tablici 3. 
Tablica 3. Demografske karakteristike ispitanika u analizi 2

\begin{tabular}{|c|c|c|}
\hline & Broj & Udio \\
\hline \multicolumn{3}{|l|}{ Spol } \\
\hline $\mathrm{M}$ & 42 & 35,6 \\
\hline$\check{Z}$ & 76 & 64,4 \\
\hline \multicolumn{3}{|l|}{ Dob } \\
\hline $18-25$ & 45 & 38,1 \\
\hline $25-30$ & 44 & 37,3 \\
\hline $30-35$ & 13 & 11,0 \\
\hline $35-40$ & 2 & 1,7 \\
\hline $40-50$ & 14 & 11,9 \\
\hline \multicolumn{3}{|l|}{ Obrazovanje } \\
\hline Magistar & 36 & 30,5 \\
\hline Prvostupnik & 37 & 31,4 \\
\hline Srednja škola & 45 & 38,1 \\
\hline \multicolumn{3}{|l|}{ Bračni status } \\
\hline Neoženjen/Neudana & 86 & 72,9 \\
\hline Oženjen/Udana & 28 & 23,7 \\
\hline Razveden/Razvedena & 4 & 3,4 \\
\hline $\mathbf{N}$ & 118 & 100,0 \\
\hline
\end{tabular}

Kako bi se testirale hipoteze H2 i H3, koristila se binarna logistička regresija s interakcijskim efektima. Prije same analize, napravljena je psihometrijska provjera mjerne ljestvice kozmopolitizma te je utvrđeno da mjerna ljestvica zadovoljava kriterije pouzdanosti i valjanosti (Cronbach $\alpha=0.94$; faktorska opterećenja čestica na konstrukt su se kretala u rasponu 0.86 - 0.94). Nakon provjere metrijskih karakteristika, analizirali su se deskriptivni podatci iz analize 2 (aritmetička sredina, standardna devijacija varijabli uključenih u model te njihove međusobne korelacije). Rezultati deskriptivne statistike su prikazani u Tablici 4.

Tablica 4. Deskriptivna statistika i međukorelacijska matrica

\begin{tabular}{|l|c|c|c|c|c|c|c|c|}
\hline & A & SD & $\mathbf{1}$ & $\mathbf{2}$ & $\mathbf{3}$ & $\mathbf{4}$ & $\mathbf{5}$ & $\mathbf{6}$ \\
\hline Dob & 2,12 & 1,27 & & & & & & \\
\hline Razina obrazovanja & 0,92 & 0,82 &,- 040 & & & & & \\
\hline Bračni status & 0,27 & 0,44 &, $633^{* *}$ &,- 105 & & & & \\
\hline Učestalost putovanja & 2,17 & 1 &, 144 &, 180 &, 087 & & & \\
\hline Kozmopolitizam & 5,84 & 1,39 &, 036 &, 027 &,- 014 &, 119 & & \\
\hline Izloženost medijima & 2,7 & 0,98 &,- 006 &,- 080 &,- 145 &,- 061 &,- 103 & \\
\hline Namjera posjete & 0,59 & 0,49 &, 037 &, 007 &, 001 &, $433^{* *}$ &, $235^{*}$ &,- 057 \\
\hline
\end{tabular}

**. Korelacija je značajna na razini 0.01

*. Korelacija je značajna na razini 0.05 
Nadalje, kako bi se pristupilo ispravnoj procjeni modela napravljeno je centriranje varijabli u odnosu na aritmetičku sredinu nakon čega su napravljeni interakcijski efekti između varijabli „,izloženost medijima“ i ,kozmopolitizam“. Analizirala su se tri modela. Prvi model je uključivao kontrolne varijable, drugi model izravne efekte te je treći model uključio interakcijski efekt. Rezultati binarne logističke regresije su prikazani u Tablici 5.

Tablica 5. Rezultati binarne logističke regresije

\begin{tabular}{|c|c|c|c|c|c|c|}
\hline & B & S.E. & Wald & df & Sig. & $\operatorname{Exp}(B)$ \\
\hline \multicolumn{7}{|c|}{$\begin{array}{c}\text { Zavisna varijabla = Namjera posjete destinaciji koja je bila pogođena } \\
\text { terorističkim napadom }\end{array}$} \\
\hline \multicolumn{7}{|c|}{ Prediktori } \\
\hline Kontrolne varijable &,- 002 & 232 & 000 & 1 & ,994 & ,998 \\
\hline Dob &,- 002 & 232 & ,000 & 1 & ,994 & ,998 \\
\hline Razina obrazovanja &,- 406 & 291 & 1,949 & 1 &, 163 & ,666 \\
\hline Bračni status &,- 558 & 663 & ,708 & 1 & 400 &, 573 \\
\hline Učestalost putovanja & 1,156 & 288 & 16,138 & 1 & ,000 & 3,176 \\
\hline \multicolumn{7}{|l|}{ Glavni efekti } \\
\hline Medijska izloženost (MED) &,- 217 & ,286 &, 576 & 1 & ,448 &, 805 \\
\hline Kozmopolitizam (COS) &, 320 & ,203 & 2,493 & 1 &, 114 & 1,378 \\
\hline \multicolumn{7}{|l|}{ Interakcijski efekti } \\
\hline MED x COS &, 496 &, 251 & 3,893 & 1 &, 048 & 1,642 \\
\hline Constant & $-1,343$ & ,678 & 3,929 & 1 &, 047 & ,261 \\
\hline
\end{tabular}

Napomena: $\mathrm{R}^{2}=.27$ (Cox \& Snell), .37 (Nagelkerke). Model $\chi 2(7)=37.89, \mathrm{p}<.01$.

Prema rezultatima istraživanja uočljivo je kako izravni utjecaj izloženosti medijskim objavama o terorizmu na namjeru posjete destinaciji nije značajan $(\beta=-.217, \mathrm{p}>0.05)$ što vodi odbijanju hipoteze H2. Međutim, interakcijski efekt kozmopolitizma i izloženosti medijskim objavama o terorističkim ugrozama ukazuje na pozitivnu i značajnu vezu s namjerom posjete destinaciji koja je bila pogođena terorističkim napadom $(\beta=.496, \mathrm{p}<0.05)$ te se H3 može prihvatiti kao istinita. Na slici 2 su prikazani rezultati interakcijskog efekta. 


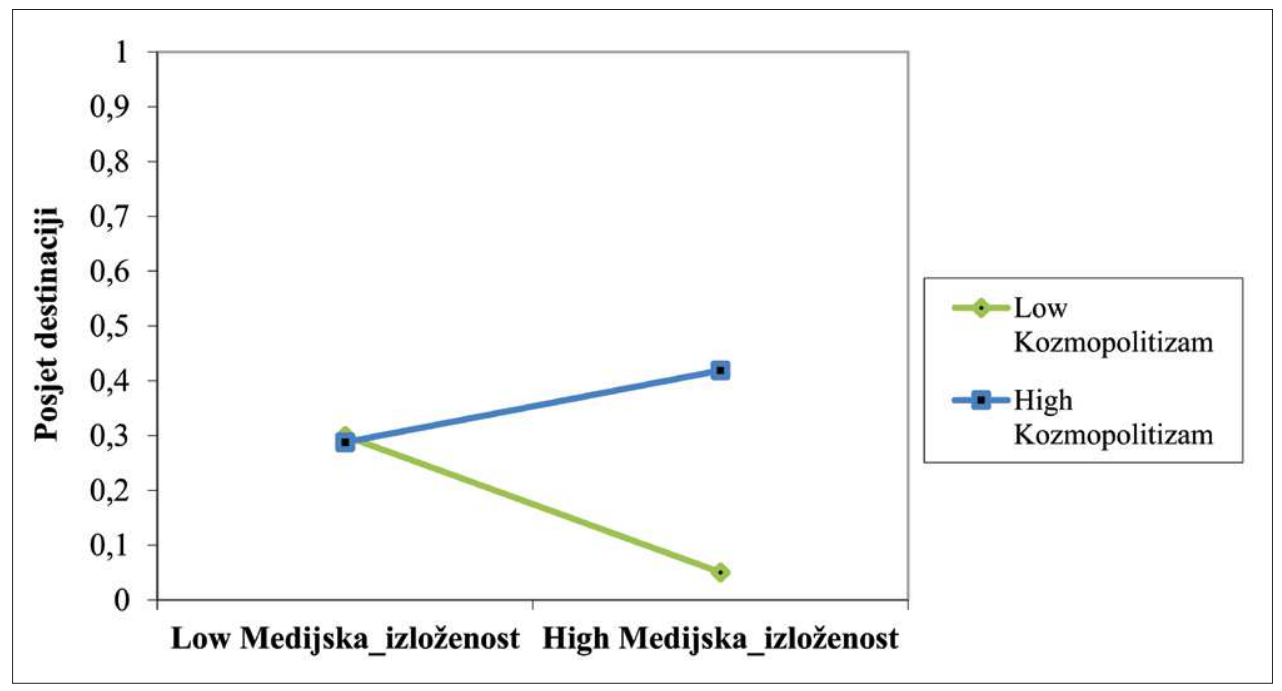

Slika 2. Interakcijski efekt

Što se tiče utjecaja kontrolnih varijabli, istraživanje je potvrdilo da su osobe koje više putuju sklonije posjetu destinacijama pogođenim terorizmom. Nastavno, rezultati ukazuju kako dob, razina obrazovanja i bračni status nemaju značajnu vezu na namjeru posjete destinaciji koja je bila pogođena terorističkim napadom.

\section{ZAKLJUČAK}

\subsection{Diskusija rezultata}

Provedena istraživanja u ovom radu doprinose novim teorijskim spoznajama literaturi koja izučava interakciju turizma i terorizma. Rezultati istraživanja ukazuju kako je sigurnost bitan čimbenik pri donošenju odluke o odabiru destinacije za putovanje. Uočeno je kako u kulturama koje imaju viši stupanj izbjegavanja neizvjesnosti sigurnost predstavlja značajan faktor turistima pri odabiru destinacije za putovanje. Kako bi razumjeli namjeru turista da posjeti destinaciju pogođenu terorizmom, potrebno je uzeti u obzir njegovo iskustvo, demografiju, identitet i informiranost. $\mathrm{U}$ ovom radu fokus je stavljen na istraživanje utjecaja izloženosti medijskim objavama o terorističkim ugrozama na spremnost posjete destinaciji koja je bila pogođena terorističkim napadom. Inflacija vijesti o terorističkim napadima može stvoriti strah kod potencijalnih turista, te će oni zbog percipiranog straha imati manju sklonost posjetiti destinaciju pogođenu terorizmom. Izvještavanje temeljeno na činjenicama, a ne na privlačenju što većeg broja klikova bi uvelike pomoglo smanjenju percipiranog straha. Međutim, rezultati istraživanja su pokazali kako izravna veza između izloženosti medijskim objavama o terorističkim ugrozama i namjere posjete destinaciji nije značajna što ukazuje na postojanje čimbenika koji bi mogli uvjetovati tu vezu. U prilog objašnjenju uvjetne veze, nalazi provedenog istraživanja su ukazali statistički značajan moderirajući utjecaj kozmopolitskog identiteta kojim pojedinci minimiziraju negativne 
učinke medijskih objava. Turisti s visoko razvijenim kozmopolitskim identitetom su manje podložni negativnom utjecaju medijskog izvještavanja o terorističkim ugrozama. Turisti koji su kozmopoliti imaju spremnost na interakciju s novim kulturama kako bi stekli nova iskustva i spoznaje. Njihova osobna potreba za sigurnošću je nadvladana urođenom željom za istraživanjem i upoznavanjem drugih kultura. Kako su teroristički napadi u nekim destinacijama i zemljama učestala pojava, to ne znači i manju turističku aktivnost. Rezultati ovog istraživanja ukazuju da unatoč negativnom utjecaju medija, turisti koji imaju razvijen kozmopolitski identitet će i dalje biti spremni posjetiti destinaciju koja je bila pogođena terorističkim napadom. Nasuprot tome, grupa turista koji su manji kozmopoliti će se u slučaju povećane izloženosti medijskim objavama teže odlučiti na putovanje u destinaciju koja bila pogođena terorističkim napadom.

\subsection{Implikacije za praksu}

Rezultati ovog istraživanja imaju i implikacije za praksu na razini turističke destinacije kao cjeline u fazi planiranja i provedbe. U fazi planiranja, turističke destinacije, posebice one čije gospodarstvo značajno ovisi o turizmu (primjerice Mediteranske zemlje), moraju implementirati strategije kriznog menadžmenta kako bi se nosile s terorističkim ugrozama (Bilandžić i Lucić, 2015). Imperativ za destinacije je implementirati krizni menadžment s marketinškim naporima kako bi povratile izgubljeni interes turista i ponovno izgradile pozitivan imidž. Jednom kada se situacija identificira kao krizna, potrebno je započeti s kriznim menadžmentom dok se ne postigne puni oporavak. Destinacije koje su podložne napadima, trebale bi barem provodit osnovne mjere pripreme za krizu u turizmu.

Rezultati su ukazali kako kulturološki profil analiziran kroz prizmu stupnja izbjegavanja neizvjesnosti značajno utječe na važnost faktora sigurnosti pri odabiru destinacije za putovanje. Destinacije mogu iskoristiti ove nalaze u svrhu kvalitetne provedbe promotivnih strategija unutar kojih bi pojačali isticanje sigurnosnog faktora u svojim destinacijama, a usmjerenima prema potencijalnim turistima iz emitivnih tržišta koja su karakterizirana visokim stupnjem izbjegavanja neizvjesnosti. Također u suradnji s medijima, posebna pozornost se treba pokloniti umanjivanju negativnih učinaka koje imaju medijske objave o terorističkim napadima.

Kako bi se predvidio utjecaj terorizma i ostalih ugroza na proces donošenja odluka turista, potrebno je u toj analizi uključiti percepciju rizika te prethodna iskustva prilikom putovanja. Dolnicar (2007) navodi kako globalni politički događaji poput terorističkih napada i epidemija podižu svijest o važnosti percepcije rizika u turizmu. Ponekad je percipirani rizik veći od stvarnog rizika. Ova tema je od velike važnosti za turističku industriju, iz razloga što je takve događaje teško predvidjeti te se mogu dogoditi u svakom trenutku i na svakom mjestu. Posljedično tome potrebno je pokušati razumjeti brige koje imaju potencijalni turisti te njihovu spremnost da posjete destinaciju koja je bila pogođena terorističkim napadom.

\subsection{Ograničenja istraživanja}

Osim doprinosa za teoriju i praksu koje ovaj rad donosi, potrebno je uzeti u obzir određena ograničenja ovog istraživanja. Većina ispitanika u provedenim istraživanjima su bili visokoobrazovani (koji su inače u ukupnoj populaciji manjina) te zbog toga rezultati 
ne ocrtavaju najbolje prosječnog putnika. Dosadašnja literatura ukazuje kako starije osobe, osobe s djecom, osobe nižeg stupnja obrazovanja te osobe koje manje putuju često imaju viši percipirani rizik i strah od nepoznatog (Sönmez i Graefe, 1998; Yang, Sharif i Khoo-Lattimore, 2015). Također osobe koje se odlučuju na ispunjavanje online anketa često su i sami zainteresirani za slična područja ili spadaju u istu društvenu skupinu (npr. studenti). U budućim istraživanjima nužno je uključiti i starije ispitanike jer će to sigurno utjecati na dobivene rezultate, bez obzira na kozmopolitski status, jer su mlađi ljudi hrabriji i spremniji izlaganju rizičnim situacijama od starijih, pa je tako i u organizaciji turističkih putovanja. Nadalje, u ovom radu se nisu istražile moguće razlike između domaćih i inozemnih turista na mogućnosti terorističkih ugroza. Postojeća literatura ukazuje da bi ove dvije skupine mogle imati različite percepcije te intenzitet reakcije na ugrozu i posljedično na namjeru putovanja (Adeloye i Brown, 2018; Seabra, Abrantes i Kastenholz, 2014). Osim navedenih socio-demografskih obilježja niz je drugih faktora koji mogu utjecati na donošenje odluke potencijalnih turista. Također, opisno istraživanje korišteno u ovom radu se može smatrati svojevrsnim ograničenjem. Buduća istraživanja bi korištenjem eksperimentalnog nacrta istraživanja mogla uočiti različite reakcije putnika na medijske objave o terorističkim ugrozama te na taj način mjeriti uzročni utjecaj na namjeru putovanja.

\section{LITERATURA}

1. Adeloye, D., \& Brown, L. (2018). Terrorism and domestic tourist risk perceptions. Journal of Tourism and Cultural Change, 16(3), 217-233.

2. Albu, C. E. (2016). Tourism and terrorism: A worldwide perspective. CES Working Papers, 8(1), 1-19.

3. Araña, J. E., \& León, C. J. (2008). The impact of terrorism on tourism demand. Annals of Tourism Research, 35(2), 299-315.

4. Baker, D. M. A. (2014). The effects of terrorism on the travel and tourism industry. International Journal of Religious Tourism and Pilgrimage, 2(1), 9

5. Baldwin, D. A. (1997). The concept of security. Review of international studies, 23 (1), 5-26.

6. Bi, J., \& Gu, C. (2019). Cultural distance and international tourists' intention to visit a destination. Asia Pacific Journal of Tourism Research, 24(8), 839-849.

7. Bianchi, R. (2006). Tourism and the globalisation of fear: Analysing the politics of risk and (in) security in global travel. Tourism and Hospitality Research, 7(1), 64-74.

8. Bilandžić, M; Lucić, D. (2015) „Gospodarska moć država i terorizam: mediteranske države kao središte svjetskog turizma i meta terorizma“, Zbornik radova Veleučilišta u Šibeniku, Zbornik radova 2. međunarodne znanstveno-stručne konferencije „Izazovi današnjice: turizam i lokalni razvoj"“

9. Chaliand, G., Chaliand, G., \& Blin, A. (Eds.). (2007). The history of terrorism: From antiquity to al Qaeda. Univ of California Press.

10. Cleveland, M., Laroche, M., Takahashi, I., \& Erdoğan, S. (2014). Cross-linguistic validation of a unidimensional scale for cosmopolitanism. Journal of Business Rese$\operatorname{arch,67(3),268-277.~}$ 
11. Crompton, J. L. (1979). Motivations for pleasure vacation. Annals of tourism research, 6(4), 408-424

12. Dabić, M., Mikulić, J. \& Ivan Novak. (2017). Framing research at the tourism and terrorism nexus. Acta turistica 29, no. 2 (2017): 181-212.

13. Dolnicar, S. (2007). Crises' that scare tourists: Investigating tourists' travel-related concerns. Crisis management in tourism, 98-109.

14. Dominguez P., Burguete E. \& Bernard A. (2007). The effect of September 11th on Mexican hotel industry, Esudios y Perscpectivas en Turismo, 334-338

15. Esmail, H. A. H. (2016). Impact of Terrorism and instability on the tourism industry in Egypt and Tunisia after Revolution. The Business \& Management Review, 7(5), 469.

16. Fuchs, G., Uriely, N., Reichel, A., \& Maoz, D. (2013). Vacationing in a terror-stricken destination: Tourists' risk perceptions and rationalizations. Journal of Travel Research, 52(2), 182-191.

17. Hajibaba, H., \& Dolnicar, S. (2018). 21 Helping when Disaster Hits. PEER-TO-PEER ACCOMMODATION NETWORKS.

18. Hajibaba, H., Gretzel, U., Leisch, F., \& Dolnicar, S. (2015). Crisis-resistant tourists. Annals of Tourism Research, 53, 46-60.

19. Hannerz, U. (1990). Cosmopolitans and locals in world culture. Theory, Culture \& Society, 7(2-3), pp.237-251.

20. Hoffman, A. M., Kowal, C., \& Kaire de Francisco, J. (2013). Terrorism coverage and the fear of terrorism. In APSA 2013 Annual Meeting Paper

21. Hofstede, G., Hofstede, GJ, \& Minkov, M.(2010). Cultures and organizations: Software of the mind. New York, NY: McGraw-Hill

22. Horjan, A. M., \& Šuperina, M. (2012). Izgradnja strategije unutarnje sigurnosti Europske unije: U pet koraka prema sigurnijoj Europi. Policija i sigurnost, 21(1), 70-104.

23. Jurišić, J., \& Šapit, M. (2005). Utjecaj terorizma na ulogu i djelovanje medija. Politička misao, 42(4), 115-128.

24. Kapuściński, G., \& Richards, B. (2016). News framing effects on destination risk perception. Tourism Management, 57, 234-244.

25. Kim, H., Schroeder, A., \& Pennington-Gray, L. (2016). Does culture influence risk perceptions? Tourism Review International, 20(1), 11-28.

26. Korstanje, M. (2009). RE-VISITING RISK PERCEPTION THEORY IN THE CONTEXT OF TRAVEL. E-Review of Tourism Research, 7(4).

27. Korstanje, M. E., \& Clayton, A. (2012). Tourism and terrorism: conflicts and commonalities. Worldwide Hospitality and Tourism Themes, 4(1), 8-25.

28. Korstanje, M. E. (2017). Terrorism, Tourism and the End of Hospitality in the'West'. Springer.

29. Larsen, S., Brun, W., Øgaard, T., \& Selstad, L. (2011). Effects of sudden and dramatic events on travel desire and risk judgments. Scandinavian Journal of Hospitality and Tourism, 11(3), 268-285.

30. Lepp, A., \& Gibson, H. (2003). Tourist roles, perceived risk and international tourism. Annals of tourism research, 30(3), 606-624. 
31. Lopes, L. L. (1987). Between hope and fear: The psychology of risk. In Advances in experimental social psychology (Vol. 20, pp. 255-295). Academic Press.

32. Mansfeld, Y., \& Pizam, A. (Eds.). (2006). Tourism, security and safety. Routledge.

33. Pađen, B. (2014). Dekonstrukcija mita o globalnom terorizmu: trendovi u suvremenom terorizmu. Međunarodne studije: časopis za međunarodne odnose, vanjsku politiku i diplomaciju, 14(2), 49-65.

34. Park, K., \& Reisinger, Y. (2010). Differences in the perceived influence of natural disasters and travel risk on international travel. Tourism Geographies, 12(1), 1-24.

35. Perešin, A. (2007). Mass media and Terrorism. Medijska istraživanja: znanstveno-stručni časopis za novinarstvo i medije, 13(1), 5-18.

36. Plog, S. C. (2002). The power of psychographics and the concept of venturesomeness. Journal of travel research, 40(3), 244-251.

37. Pizam, A., \& Mansfeld, Y. (1996). Tourism, crime, and international security issues. John Wiley \& Son Ltd.

38. Pizam, A., Tarlow, P. E., \& Bloom, J. (1997). Making tourists feel safe: Whose responsibility is it?. Journal of travel research, 36(1), 23-28.

39. Reisinger, Y., \& Mavondo, F. (2005). Travel anxiety and intentions to travel internationally: Implications of travel risk perception. Journal of travel research, 43(3), 212-225.

40. Richter, L. K., \& Waugh Jr, W. L. (1986). Terrorism and tourism as logical companions. Tourism Management, 7(4), 230-238.

41. Roehl, W. S., \& Fesenmaier, D. R. (1992). Risk perceptions and pleasure travel: An exploratory analysis. Journal of Travel research, 30(4), 17-26.

42. Schlagheck, C. (1998). Newspaper reading choices by college students. Newspaper Research Journal, 19(2), 74-87.

43. Schmid, A. (2005). Terrorism as psychological warfare. Democracy and Security, 1(2), 137-146.

44. Schmid, A. P. (Ed.). (2011). The Routledge handbook of terrorism research. Taylor \& Francis.

45. Seabra, C., Abrantes, J. L., \& Kastenholz, E. (2014). The influence of terrorism risk perception on purchase involvement and safety concern of international travellers. Journal of Marketing Management, 30(9-10), 874-903.

46. Servier J., (2002): Terorismul, Institutul European, Iasi

47. Sheng-Hshiung, T., Gwo-Hshiung, T., \& Kuo-Ching, W. (1997). Evaluating tourist risks from fuzzy perspectives. Annals of Tourism Research, 24(4), 796-812.

48. Sönmez, S. F., \& Graefe, A. R. (1998). Determining future travel behavior from past travel experience and perceptions of risk and safety. Journal of travel research, 37(2), 171-177.

49. Sönmez, S. F., \& Graefe, A. R. (1998). Influence of terrorism risk on foreign tourism decisions. Annals of tourism research, 25(1), 112-144.

50. Sönmez, S. F., \& Backman, S. J. (1992). Crisis management in tourist destinations. Visions in Leisure and Business, 11, 24-24. 
51. Sönmez, S. F. (1998). Tourism, terrorism, and political instability. Annals of tourism research, 25(2), 416-456.

52. Sönmez, S. F., Apostolopoulos, Y., \& Tarlow, P. (1999). Tourism in crisis: Managing the effects of terrorism. Journal of travel research, 38(1), 13-18.

53. Swain, M. B. (2009). The cosmopolitan hope of tourism: Critical action and worldmaking vistas. Tourism Geographies, 11(4), 505-525.

54. Tarlow, P. E., \& Goldblatt, J. (2002). Event risk management and safety. J. Wiley.

55. Tarlow, P. (2011). Tourism disaster management in an age of terrorism. International Journal of Tourism Anthropology, 1(3-4), 254-272.

56. The European union counter - terrorism strategy, preuzeto sa The European union counter - terrorism strategy

57. Venner D., (2005): Povijest terorizma, Alfa, Zagreb

58. World Tourism Organization. (1997). Tourist safety and security: practical measures for destinations. World Tourism Organization., 1996, preuzeto sa UNWTO.com

59. Walters, G., Wallin, A., \& Hartley, N. (2019). The threat of terrorism and tourist choice behavior. Journal of Travel Research, 58(3), 370-382.

60. Wilkinson P., (2002): Terorizam protiv demokracije, Golden Marketing, Zagreb

61. Wolfendale, J. (2007). Terrorism, security, and the threat of counterterrorism. Studies in Conflict \& Terrorism, 30(1), 75-92.

62. Yang, E. C. L., Sharif, S. P., \& Khoo-Lattimore, C. (2015). Tourists' risk perception of risky destinations: The case of Sabah's eastern coast. Tourism and Hospitality Research, 15(3), 206-221. 